\title{
The role of vowel length in comprehension during cross-cultural communication: An action research project
}

\author{
Gareth Morgan \\ Hertford College, Oxford University, Catte Street, Oxford
}

\section{Abstract}

The paper describes the process and outcomes of an action research project with the aim of determining whether focusing classroom input on vowel length has a positive effect on the production and comprehension of these sounds. The statistics were generated from respondents listening to the output of speakers from an experimental group, who had received instruction on this issue, and to the output of speakers from a control group, who had not been provided with any input, with the rate of intelligibility being compared. The conclusion drawn is that the provision of input on vowel length does, generally speaking, make a difference to a speaker's comprehensibility.

\section{Keywords}

Pronunciation, L1 interference, Vowel length, Cross-cultural communication.

\section{Introduction}

Though Jenkins (2000) comments on pronunciation being essential in maximizing communicative effectiveness, it regularly impedes successful communication in international contexts, as non-native speakers are more dependent on this feature of oral interaction because they have less recourse to contextualization (Brown, 1989). The transference of phonological features from the mother tongue can cause pronunciation problems while communicating in an international context, and this can be exacerbated if bottom-up approaches are used for speech processing. This involves attempting to comprehend speech by analyzing individual sounds, to understand the entire turn, as opposed to implementing the topdown approaches, which, in contrast, make use of background information to predict meaning, and involve developing expectations about what will be heard. Jenkins (2000) goes on to say that a mastery of the Lingua Franca Core, phonological features which cause intelligibility problems for an audience from differing language backgrounds, based on data derived from her multilingual classes, can result in mutual intelligibility among L2 speakers.

Mutually intelligibility is increasingly pertinent due to the sheer volume of non-native speaker - non-native speaker interaction, as commented on by Kirkpatrick (2010), and the fact that "native speaker models have limited relevance to these new contexts of use" (Pickering, 2006, p.219). Jenkins (2000) believes this to be an issue which needs to be explicitly addressed in the classroom, with the focus on teachable and learnable aspects of pronunciation. Her thesis is based on the research conducted on intelligibility errors among non-native speakers, and includes the avoidance of deviant core sound production. This includes differentiating between the long and short vowels, which aids in the production of intelligible language, as well as the ability to comprehend spoken English.

\section{Background}

Though there is no single agreed upon pronunciation according to Dauer (2005), Kachru (2005) positions Singapore English in English's outer circle, and laments the fact that reference is made to the inner circle for the norms, given that English belongs to the outer circle as much as anyone, due to the sheer volume of non-native speakers there are. Similarly, Deterding (2010) comments on there being three English diaspora, with Singapore English being in the third, which is comprised of countries which were former colonies of the British Empire. This diaspora is characterised by significant influences caused by indigenous languages. Consequently, significant differences exist between Standard English and Singapore English, with the latter being regarded as having diverged from the norm.

There are now more outer or extended circle speakers, who number between 300 to 500 million in the countries where English is used institutionally in over 50 countries, including Singapore, with a further 500-1,000 million people in the expanding or extending circle, such as China, where it is recognized as being important. In comparison, there are between 320 to 380 million speakers in the inner circle (Crystal, 2003).

Dauer (2005) comments on vowel length being a feature of pronunciation which is not even mastered by very fluent speakers, and, generally speaking, one way in which Singapore English differs from the inner circle variety is the absence of vowel length distinction. This absence of vowel length distinction is a feature which Kirkpatrick (2010) states to be also true of the Southeast Asian English of Brunei and Malaysia, for example. Furthermore, this issue extends beyond Southeast Asia to locations such as Pakistan, where native Urdu speakers are affected (Sheikh, 2012), and countries with Spanish as the mother tongue (Lin, 2014), even though Deterding, Brown and Low (2005) state that vowel length occurs “... [l]n virtually all accents of English...” (p.124). 


\section{ISSN $2348-3024$ \\ Volume $7 \mathrm{Number} 1$ \\ Journal of Advances in Linguistics}

Though length can vary according to the presence or absence of stress (Roach, 1991), as well as vowel height with regard to the tongue's position (McArthur, 1998), vowel length distinction involves distinguishing the 5 long vowel sounds, /i:/, /u:/, /o:/, /a:/, and /3:/, which have a greater duration than the short vowel sounds in similar sound contexts.

Deterding (2007) is of the opinion that research on vowel length distinction is the most widely described feature of the vowels of Singaporean English. This dialect has been found to lack the distinction between long and short vowel pairs, with the neutralisation of length distinctions often occurring due to the shortening of the long vowel sounds (Deterding, 2003). Low and Brown (2005) support this claim, stating the Singaporean tendency to pronounce four of the five long vowels as fairly short (with /3:/ being the exception). Similarly, Lim (2004) states that beat and bit, cart and cut, caught and cot, and pool and pull are "produced as virtual homophones" (p.20), while Brown (2001) asserts that minimal pairs featuring the long vowels tend to be conflated and pronounced as the short vowel, thus creating homophones.

Deterding et al (2005) believe that this is the reason why Singaporean trainee teachers ranked teaching pronunciation as being much more important than International trainee teachers, in their research. The Singaporean trainee teachers ranked phonemic vowel length second on a list of 29 items, compared to their international colleagues' ranking of 13, with authors claiming that this could be due to trainees being given input on the conflation of the long and short vowel phonemes in Singapore English.

Jenkins (2000) claims that inaccurate pronunciation is the most common source of loss of oral comprehension, with segmental features figuring prominently. This includes the loss of vowel length distinction, which she regards as being essential for the maintenance of intelligibility in international English, because the absence of this distinction is an issue which may prevent successful communication in international contexts, even though it may not necessarily cause communication breakdowns.

The issue is further exacerbated due to non-native speakers primarily using the previously mentioned bottom-up processing, and having less recourse to contextual or syntactical information than native speakers, a theory supported by both Deterding (2005) and Field (2004), whose research concluded that non-native learners are heavily reliant on word level interpretations. Brown (1988) concurs with vowel length being a source of communication breakdown, due to this distinction carrying a high functional load in separating a large number of words, as does Date (2005), who comments on the issue as being extremely important from a Japanese perspective, with the absence of long vowel sounds leading to reduced intelligibility, especially when a shortened vowel is followed by a glotalised $/ \mathrm{t} / \mathrm{or} / \mathrm{d} /$.

On the other hand, Ali (2013) claims there is no serious problem with vowel duration for Sudanese Arabic speakers, as there is correspondence between English and the mother tongue, while the inability to distinguish between these minimal pairs does not have a significantly negative impact on British listeners' comprehension, according to Deterding et al (2005).

Furthermore, in interviews with Singaporean speakers conducted by Deterding (2003), most instances of miscommunication resulted from issues with intonation. With regard to segmental problems, the most common misunderstandings occurred with missing or extra -s plural suffixes. Miscommunication due to vowel usage was uncommon, occurring only twice, with neither instance related to vowel length, resulting in his conclusion that the loss of vowel distinctions does not cause communication breakdown. It should be noted though that he does mitigate this comment by stating the fact that he had been in Singapore for over nine years at the time of the interviews, and nonSingaporeans with less experience might have had more difficulty comprehending than he did. In support of this theory, Gupta (2005) comments on the fact that Singaporeans not distinguishing between long and short vowels did not cause incomprehension for British listeners.

Moreover, Derwing and Munro (1997) claim that comprehension has as much to do with grammatical and prosodic proficiency as pronunciation, while it has also been explained that there are other factors to be taken into consideration, such as external noise (Rogers, Dalby \& Nishi, 2004), lexical variations, including idiomatic usage (Seidlhofer, 2001), and vocabulary the listeners in a conversation are unfamiliar with (Meierkord, 2004).

Deterding (2003) does also state that in the conversational speech of educated Singaporean speakers of English there is indeed neutralisation between /i:/ and / I / with no distinction maintained (as well as between /e/ and /æ/), and only a subtle difference between $/ 0: /$ and / $/$ /. However, he then says that the fewer vowel contrasts in the SgE data do not contribute to problems in cross-cultural communication nearly as much as differences in intonation.

Therefore, the aim of this research was to determine if the provision of overt pronunciation input regarding vowel length had a beneficial effect on Singaporeans' production of long vowel sounds, and whether or not it benefitted an international audience's comprehension, helping to alleviate miscommunication and the loss of intelligibility during inter-cultural communication. 


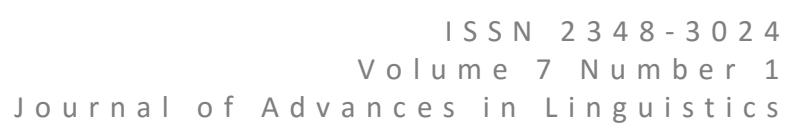

\section{The project}

The participants in the project were native Singaporean undergraduates undertaking a one-semester English for Academic Purposes course at the National University of Singapore, which focussed on Academic Writing. For the purpose of the research, an optional three-hour supplementary workshop on pronunciation issues focussing on individual problematic sounds, including long vowels was provided independently of the course schedule. The rationale for the provision of the input was that it would help the students with the clarity of their graded presentations. Consequently, 21 of the 54 students chose to attend.

Firstly, students were introduced to the International Phonemic Alphabet (IPA) through the websites listed in Appendix A, with a wordsearch (Appendix B) and a crossword (Appendix C) undertaken in small groups to promote learner autonomy. Activities were then conducted which specifically focussed on the contrast between the long and short vowel sounds. As well as a kinaesthetic activity which had the students either with their arms in the air if a monosyllabic word had a long vowel sound or on their heads if a word contained a short vowel sound, the activities Pronunciation Journey from Hancock (2000), The Telephone Number Game (Appendix D) and Bingo (Appendix E) featured.

Post input, three students were randomly selected for the experimental group from the students who had decided to attend the workshop, and three students were randomly selected to be part of the control group from the students who had chosen not to attend the workshop. All six of the students who agreed to be recorded, with the recordings being analysed for research purposes with reference to pronunciation, were Singaporeans who had received their secondary education in the medium of English, and regarded this language as being their mother tongue.

The students were then recorded saying the long vowel sounds in the sentence sets in Appendix $F$, with each student randomly allocated one of the sets. Individual sentences were selected for recording, as opposed to longer stretches of language, in order to avoid making the answers too obvious due to the context. This is because, as previously mentioned, making use of background information to predict meaning, and developing expectations about what will be heard, are techniques which are not always implemented by listeners.

Three randomly chosen students from each group were recorded in order to negate the idiosyncrasies an individual may have shown, with their output played to a non-Singaporean audience classified according to whether they had had exposure, limited exposure, or no exposure to Singapore English, with these listeners circling the word they believed they had heard.

With reference to people with limited experience of Singapore English, the benchmark was people who had only been in the country for less than a month, meaning that the cohort was comprised of international students who had recently arrived at the National University of Singapore on scholarships. This cohort of 21 was comprised of Chinese students, apart from two Indonesian students.

The non-Singaporean audience were contacts known by myself to have not been knowingly exposed to Singapore English. They comprised 34 people, 28 of whom were native speakers from the UK, with 6 non-native English speakers, 5 of whom were Thai, with the other person being Indian. The respondents who had been exposed to Singapore English were from the UK, USA, China, Gibraltar, France, Australia, The Philippines, Indonesia, Taiwan, Japan, Italy, South Africa, Thailand, India, Myanmar and Vietnam, and had been residing in Singapore for at least 2 years at the time of the project.

It should be noted that Malaysians were purposefully excluded from the audience due to the well documented similarities between Malaysian English and Singaporean English. For example, Low (2010) comments on there being many phonological similarities between the two varieties, and Platt and Webber (1980) classify both varieties as one.

\section{Results}

The statistics were categorized according to the amount of exposure to Singapore English, and whether or not the respondents' mother tongue was English, with the results from the research highlighting that the students from the experimental group outperformed the students from the control group in every form of data analysis.

With regard to responses from those with experience of Singapore English, meaning people who had been living in the country for at least two years, 255 sentences were analysed for each of the groups, making a total of 510 . The respondents were from a variety of countries, including nations where English is not the national language. To break down the data, there were 32 native speakers of English, and 19 non-native speakers. The native speakers included 17 people from the UK, 11 from the USA, 2 from Gibraltar an Australian and a South African. The non-native speakers comprised 7 people from China, 3 from The Philippines, 2 from Indonesia, 2 from Japan, and 1 from each of the following countries: France, Italy, Myanmar, Taiwan, and Vietnam. Also, it should be noted that a variety of ages were represented, ranging from early teens to mid-50s, as well as both sexes.

1137 | P a g e

A u gust, 2016 council for Innovative Research ww w. cirworld.com 
For this cohort, the level of accuracy showed the least difference with a success rate of $52 \%$ for the experimental group, compared to $48 \%$ for the control group. The difference was mainly due to the responses for /u:/ with exactly twice as many people in the control group choosing the shorter vowel equivalent, such as pull instead of pool. However, for both groups the most erroneous feedback was generated by $/ \mathrm{o} /$, closely followed by $/ \mathrm{i}:$, which combined to account for $54.4 \%$ of the total. A complete breakdown of the data is provided in Table 1 below:

Table 1: Feedback from people with experience of Singapore English

$$
\begin{array}{ll}
\text { Correct answers } & \\
\text { Experimental Group } & =178=52 \% \\
\text { Control Group } & =165=48 \% \\
\text { Total } & =343 \quad(51 \text { respondents; } 510 \text { responses }=255 \text { per group })
\end{array}
$$

Sets used

Experimental Group

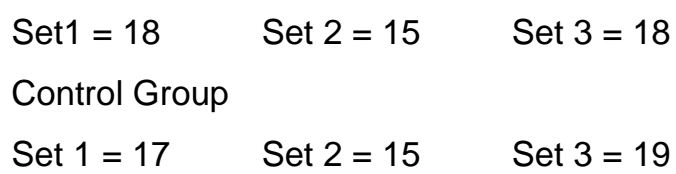

Errors

$\begin{array}{ll}\text { Experimental Group } & =77 \\ \text { Control Group }=90 & \\ \text { Total } & =167\end{array}$

Segmental errors

$\begin{array}{llll}\text { Sound } & \text { Experimental Group } & \text { Control Group } & \text { Total } \\ \text { i: } & 21 & 23 & 44(26.3 \%) \\ \text { u: } & 09 & 18 & 27(16.2 \%) \\ \text { o: } & 22 & 25 & 47(28.1 \%) \\ \text { a: } & 13 & 09 & 22(13.2 \%) \\ \text { 3: } & 12 & 15 & 27(16.2 \%)\end{array}$

Country of origin of respondents: UK 17 USA 11 China 7 The Philippines 3 Gibraltar 2 Indonesia 2 Japan 2 Australia 1 France 1 Italy 1 Myanmar 1 South Africa 1 Taiwan 1 Vietnam 1 = 32 native English speakers; 19 non-native speakers

With reference to people with limited experience of Singapore English, all successfully chose /a:/, while only one person (from the control group) incorrectly selected / $/$ / as opposed to $/ 3:$. As for the previous cohort, the majority of incorrectly chosen sounds were a result of the miscomprehension of $/ 0: /$ and / $\mathrm{i}: /$, with percentages of $50 \%$ and $35 \%$ respectively. The majority of incorrectly chosen sounds were selected by the control group, though the feedback for /u:/ was anomalous with $30 \%$ of the erroneous feedback for the experimental group generated by this sound, in comparison to the control group's error rate of $3 \%$. The data in its entirety can be seen in Table 2. 
Table 2: Feedback from people with limited experience of Singapore English

\begin{tabular}{|ll}
\hline Correct answers & \\
Experimental Group & $85=81 \%$ \\
Control Group & $73=70 \%$ \\
Total & 210 (21 respondents; 210 responses = 105 per group) \\
Sets used & $=$ Set 2 \\
Experimental Group & \\
Control Group Set 3 & \\
Errors & $=20$ \\
Experimental Group & $=52$ \\
Control Group $=32$ & \\
Total & $=52$
\end{tabular}

Segmental errors

\begin{tabular}{|c|c|c|c|c|}
\hline Sound & Experimental & Group & Control Group & Total \\
\hline $\mathrm{i}:$ & 5 & & 13 & $18(35 \%)$ \\
\hline $\mathrm{u}:$ & 6 & & 1 & $7 \quad(13 \%)$ \\
\hline 0: & 9 & & 17 & $26(50 \%)$ \\
\hline $\mathrm{a}:$ & 0 & & 0 & $0 \quad(0 \%)$ \\
\hline 3: & 0 & & 1 & $1 \quad(2 \%)$ \\
\hline
\end{tabular}

Respondents' country of origin: China 19 Indonesia 2 = 21 non-native speakers of English

The final group comprised people with no experience of Singapore English. The participants were mainly from the UK, with this cohort comprising $82 \%$ of the total, with the remaining $18 \%$ being non-native speakers from Thailand and India. Again for both the control and experimental groups, / $/ /$ generated the most errors for both categories of respondents, with erroneous responses numbering $39.5 \%$ and $34.6 \%$ respectively, while $/ 3: /$ generated the least, with the errors totalling $12.3 \%$ and $7.8 \%$ respectively. The feedback for /a:/ was practically the same for the two sets, while they were reversed for / i:/ and /u:/. Table 3 contains the data in its entirety for these respondents.

Table 3: Feedback from people with no experience of Singapore English

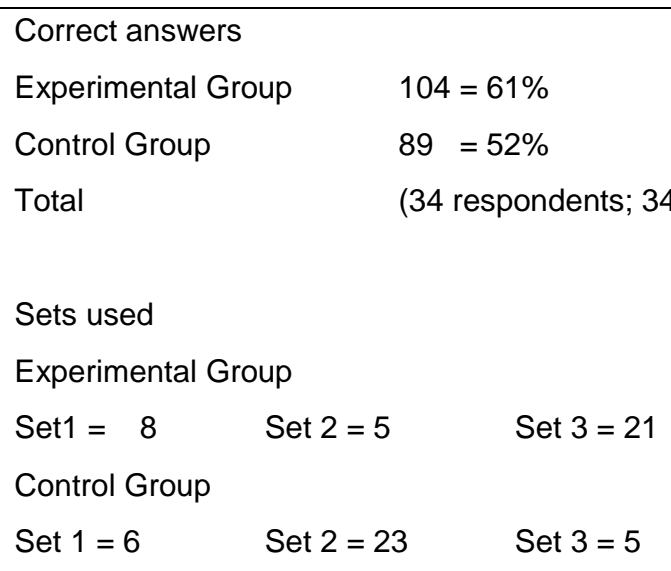




$\begin{array}{ll}\text { Errors } & \\ \text { Experimental Group } & =66 \\ \text { Control Group }=81 & \\ \text { Total } & =147\end{array}$

Segmental errors

$\begin{array}{llll}\text { Sound } & \text { Experimental Group } & \text { Control Group } & \text { Total } \\ \text { i: } & 7 & 17 & =24(16 \%) \\ \text { u: } & 16 & 11 & =17(18 \%) \\ \text { o: } & 25 & 28 & =53(36 \%) \\ \text { a: } & 14 & 15 & =29(20 \%) \\ \text { 3: } & 4 & 10 & =14(10 \%)\end{array}$

Country of origin of respondents: UK 28 Thailand 5 India 1 = 28 native speakers of English; 6 non-native speakers

To sum up, the feedback in its entirety, as shown in Table 4 below, highlights the fact that for both cohorts, $/ \mathrm{s} / /$ is the most problematic sound by far, and is equally problematic for both the experimental and the control groups. This is followed by / i:/, though it would appear that the provision of input has resulted in the experimental group generating far fewer errors. In contrast, it would appear that input regarding /a:/ and /u:/ had only a limited beneficial effect in the output being correctly interpreted.

Table 4: Research results in total

\begin{tabular}{|l|l|l|l|}
\hline Sound & $\begin{array}{l}\text { Experimental Group } \\
\text { Errors }\end{array}$ & Control Group Errors & Total Errors \\
\hline i: & $33(20.3 \%)$ & $53(26.1 \%)$ & $86(23.5 \%)$ \\
\hline u: & $31(19.1 \%)$ & $30(14.8 \%)$ & $61(16.7 \%)$ \\
\hline o: & $56(34.4 \%)$ & $70(34.5 \%)$ & $126(34.4 \%)$ \\
\hline a: & $27(16.5 \%)$ & $24(11.8 \%)$ & $51(13.9 \%)$ \\
\hline 3: & $16(9.7 \%)$ & $26(12.8 \%)$ & $42(11.5 \%)$ \\
& $=163$ & 203 & $=366$ \\
\hline
\end{tabular}

Finally, the data was analysed according to whether or not the respondents' mother tongue was English. The 47 nonnative speakers were from China, The Philippines, Thailand, Indonesia, Japan, France, Italy, Myanmar, Taiwan, India and Vietnam, and comprised $42 \%$ of the respondents, while there were 65 native speakers from the UK, USA, Gibraltar, Australia and South Africa forming the remaining $58 \%$. Statistically speaking, the proportion of errors generated by the two cohorts reflected the percentages, with the non-native speakers making $41 \%$ of the errors and native speakers $59 \%$. Therefore, whether or not the audience's mother tongue is English does not play a significant role in determining whether or not a listener can comprehend Singapore English.

Table 5: Errors based on whether or the respondents' mother tongue is English

\begin{tabular}{|l|l|l|l|}
\hline Sound & Non-native speakers & Native speakers & Total Errors \\
\hline i: & 44 & 42 & 86 \\
\hline u: & 27 & 34 & 61 \\
\hline o: & 53 & 73 & 126 \\
\hline
\end{tabular}




\begin{tabular}{|l|l|l|l|}
\hline a: & 11 & 40 & 51 \\
\hline 3: & 14 & 28 & 42 \\
\hline Total & 149 & 217 & 366 \\
\hline
\end{tabular}

\section{Conclusion}

Of all the skills, pronunciation tends to be the most neglected according to $\mathrm{Ng}$ and Lim (2005), with Ur (1996) commenting on the cause being a lack of knowledge. This has been found to be particularly the case when the teacher is inexperienced (Morgan, 2009), though many teachers, including experienced ones, lack phonetic training (Dauer, 2005). Unfortunately, even when pronunciation does feature in the classroom, a generic pronunciation tends to be taught which fails to meet learner needs as its aim is to aid students approximate their oral output to the prescribed norms (Masuhara, Haan, Yi \& Tomlinson, 2008), even though the majority of their communication is not with native speakers.

However, while inner circle native speakers are no longer in control of the English language and, therefore, need to adjust in order for an international norm to develop (Jenkins, 2002), the results suggest the provision of explicit input on vowel quantity, especially with regard to $/ \mathrm{s} /$, due to the volume of erroneous responses related to this segmental, and /i:/, for the same reason, as well as its commonality.

Vowel quantity should occur despite some research being of the opinion that covering such pronunciation issues is both time consuming and intimidating, and can result in learner failure and frustration (Walker, 2001), even if non-native varieties of pronunciation are to be legitimized, as suggested by Kachru (2003) with an acceptance of "a plurality of norms", as advocated by Bhatia (1997). This is because, as discovered in previous research, such as Robertson (2003), the results show that even if the students provided with pronunciation input did not necessarily record particularly better results than students who had received no input, the feedback was better for the former cohort, irrespective of the origin of the listener. Therefore, I am in agreement with Jenkins (2000) in the belief that a focus on this pronunciation issue for English language users, especially those who do not have the feature, should maximise the ability to effectively communicate.

\section{Acknowledgements}

I would like to extend my gratitude to the learners who agreed to be recorded, as well as all the people who responded to the recordings.

\section{References}

1. Ali, E.M.T. (2013). Pronunciation problems: acoustic analysis of the English vowels produced by Sudanese learners of English. International Journal of English and Literature, 4 (10), 495-507.

2. Bhatia, V.K. (1997). Introduction: genre analysis and world Englishes. World Englishes, 16(3), 313-319.

3. Brown, A. (1988). Vowel differences between Received Pronunciation and the English of Malaysia and Singapore: Which ones really matter? In J. Foley (Ed.), New Englishes: The case of Singapore (pp.129-147). Singapore: Singapore University Press.

4. Brown, A. (2001). Singapore English in a nutshell. Singapore: Federal Publications.

5. Brown, G. (1989). Making sense: the interaction of linguistic expression and contextual information. Applied Linguistics, 10(1), 97-108.

6. Date, T. (2005). The intelligibility of Singapore English from a Japanese perspective. In Deterding, D., Brown, A., \& Low, E. L. (Eds.), English in Singapore: Phonetic research on a corpus (pp. 173-183). Singapore: McGraw-Hill Education, Asia.

7. Dauer, M.R. (2005). The lingua franca core: A new model for pronunciation instruction? TESOL Quarterly, 39(3), 543-550.

8. Derwing, T.M., and Munro, M.J. (1997). Accent, intelligibility, and comprehensibility: Evidence from four L1s. Studies in Second Language Acquisition, 19, 1-16.

9. Deterding, D. (2003). An instrumental study of the monophthong vowels of Singapore English. English WorldWide, 24(1), 1-16.

10. Deterding, D. (2005). Listening to Estuary English in Singapore. TESOL Quarterly, 39(3), 425-440.

11. Deterding, D. (2007). Singapore English. Edinburgh: Edinburgh University Press.

12. Deterding, D. (2010). Variation across Englishes: Phonology. In A. Kirkpatrick (Ed.), The Routledge Handbook of World Englishes (pp. 385-399). London: Routledge. 


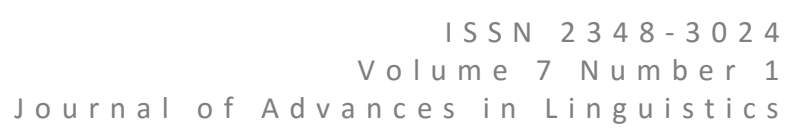

13. Deterding, D., Brown, A., and Low, E.L. (2005). English in Singapore: Phonetic research on a corpus. Singapore: McGraw Hill.

14. Field, J. (2004). An insight into listeners' problems: Too much bottom-up processing or too much top-down? System, 32, 363-377.

15. Gupta, A.F. (2005). Inter-accent and inter-cultural intelligibility: a study of listeners in Singapore and Britain. In Deterding, D., Brown, A., \& Low, E.L. English in Singapore: Phonetic research on a corpus. Singapore: McGraw Hill.

16. Hancock, M. (2000). Pronunciation Games. Cambridge: Cambridge University Press.

17. Jenkins, J. (2000). The phonology of English as an international language. Oxford: Oxford University Press.

18. Jenkins, J. (2002). A sociolinguistically based, empirically researched pronunciation syllabus for English as an international language. Applied Linguistics, 23, 83-103.

19. Kachru, B. (2003). Liberation linguistics and the Quirk concern. In B. Seidlhofer (Ed.), Controversies in applied linguistics(pp.19-32). Oxford: Oxford University Press.

20. Kachru, B.B. (2005). Asian Englishes: beyond the canon. Hong Kong: Hong Kong University Press.

21. Kirkpatrick, A. ed. (2010). The Routledge handbook of World Englishes. Abingdon: Routledge.

22. Lim, L. ed. (2004). Singapore English: A grammatical description. Amsterdam: John Benjamins.

23. Lin, L-C. (2014). Understanding pronunciation variations facing ESL students. International Journal of Humanities and Social Science, 4, 5(1), 16-20.

24. Low, E. L. (2010). English in Singapore and Malaysia: Differences and Similarities. In A. Kirkpatrick, (Ed.), The Routledge Handbook of World Englishes (pp. 229-246). Abingdon: Routledge.

25. Low, E. L. and Brown, A. (2005). English in Singapore: An introduction. Singapore: McGraw Hill.

26. Masuhara, H., Haan, M., Yi, Y. \& Tomlinson, B. (2008). Adult EFL courses. ELT Journal, 62(3), 294-312.

27. McArthur, T. (1998). The concise Oxford companion to the English language. Oxford: Oxford University Press.

28. Meierkord, C. (2004). Syntactic variation in interactions across international Englishes. English World-Wide, 25, 109-132.

29. Morgan, G. (2009). The awareness of Vietnamese adult students and their teachers to pronunciation issues. STETS Language \& Communication Review, 8(1), 19-30.

30. Ng, S. and Lim L. (2005). Appreciating language contact in pronunciation teaching: Local languages' effect on Singapore English. In Deng, X., Cole, V.M., Sadorra, M.L.C. and Wu, S.M (Eds.), Paradigm shifts in English Language teaching and learning: Selected papers from the inaugural CELC International Symposium (pp.143154). Singapore: Centre for English Language Communication, National University of Singapore.

31. Pickering, L. (2006). Current research on intelligibility in English as a lingua franca. In M. McGroarty (Ed.). Annual Review of Applied Linguistics, 26 (pp.219-233). Cambridge: Cambridge University Press.

32. Platt, J. and Weber, H. (1980). English in Singapore and Malaysia: Status, Features and Functions. Oxford: Oxford University Press.

33. Roach, A. (1991). English phonetics and phonology. Cambridge: Cambridge University Press.

34. Robertson, P. (2003). Teaching English pronunciation skills to the Asian learner: a cultural complexity or subsumed piece of cake? Asian EFL Journal. Retrieved from http://www.asian-efljournal.com/june2003subpr.php (accessed June 2014).

35. Rogers, C., Dalby, J. and Nishi, K. (2004). Effects of noise and proficiency on intelligibility of Chinese-accented English. Language and Speech, 47, 139-154.

36. Seidlhofer, B. (Ed.) (2003). Controversies in applied linguistics. Oxford: Oxford University Press.

37. Sheikh, Q. A. (2012). An analysis of the vowel sounds of Pakistani English. Bulletin of Education and Research, $34(1), 1-18$.

38. Ur, P. (1996). A course in language teaching: practice and theory. Cambridge: Cambridge University Press.

39. Walker, R. (2001). Pronunciation priorities, the Lingua Franca Core, and monolingual groups. Speak Out! Newsletters of the IATEFL Pronunciation Special Interest Group, 18 (September), 4-9.

\section{APPENDIX A:}

\section{Pronunciation Websites:}

http://www.bbc.co.uk/worldservice/learningenglish/grammar/pron/sounds/

http://www.uiowa.edu/ acadtech/phonetics/

http://www.soundsofenglish.org/pronunciation/sounds.htm

http://www.manythings.org $/ \mathrm{mp} / \mathrm{m} 30 . \mathrm{html}$

http://www.bbc.co.uk/worldservice/learningenglish/grammar/pron/unit1/start.shtml

http://shiporsheep.com/

1142 | P a g e

A u gust, 2016 council for Innovative Research ww w. cirworld.com 


\section{WORDSEARCH}

\begin{tabular}{|c|c|c|c|c|c|c|c|c|c|}
\hline œ & V & $p$ & $\mathrm{~S}$ & I & $\Lambda$ & $S$ & $\mathrm{u}:$ & $p$ & b \\
\hline$p$ & i: & $d_{3}$ & $\mathrm{k}$ & eI & $\mathrm{k}$ & $t$ & $\int$ & $\theta$ & $\partial$ \\
\hline 1 & $f$ & $t$ & $\Lambda$ & $t$ & $\mathrm{i}:$ & eI & аI & I & $n$ \\
\hline $\mathbf{j}$ & $r$ & eI & $r$ & w & $b$ & $\mathrm{k}$ & $S$ & $k$ & $a:$ \\
\hline$\theta$ & u: & $t$ & u: & $f$ & $\mathrm{t} \int$ & I & k & $\mathbf{I}$ & $\mathrm{n}$ \\
\hline i: & $t$ & 3: & $\mathrm{D}$ & I & $t$ & Z & $r$ & $\mathrm{n}$ & $\partial$ \\
\hline Z & $æ$ & I & ): & $\int$ & $\mathrm{u}$ : & $r$ & i: & w & $\mathrm{m}$ \\
\hline$\eta$ & k & $D$ & $f$ & $\mathrm{i}:$ & $p$ & $D$ & $\mathrm{~m}$ & I & $\mathrm{u}$ : \\
\hline$D$ & $\eta$ & む & $\partial$ & 1 & e & $\mathrm{m}$ & $\partial$ & $\mathrm{n}$ & $\theta$ \\
\hline $\mathrm{k}$ & $\Lambda$ & $r$ & $\mathrm{i}:$ & $\mathrm{t}$ & $\mathrm{h}$ & $d_{3}$ & u: & $S$ & a: \\
\hline
\end{tabular}

Find 15 FOOD and DRINK words. The words run horizontally or vertically. 'Apple' has been done for you. 
APPENDIX C:

\section{CLOTHES CROSSWORD}

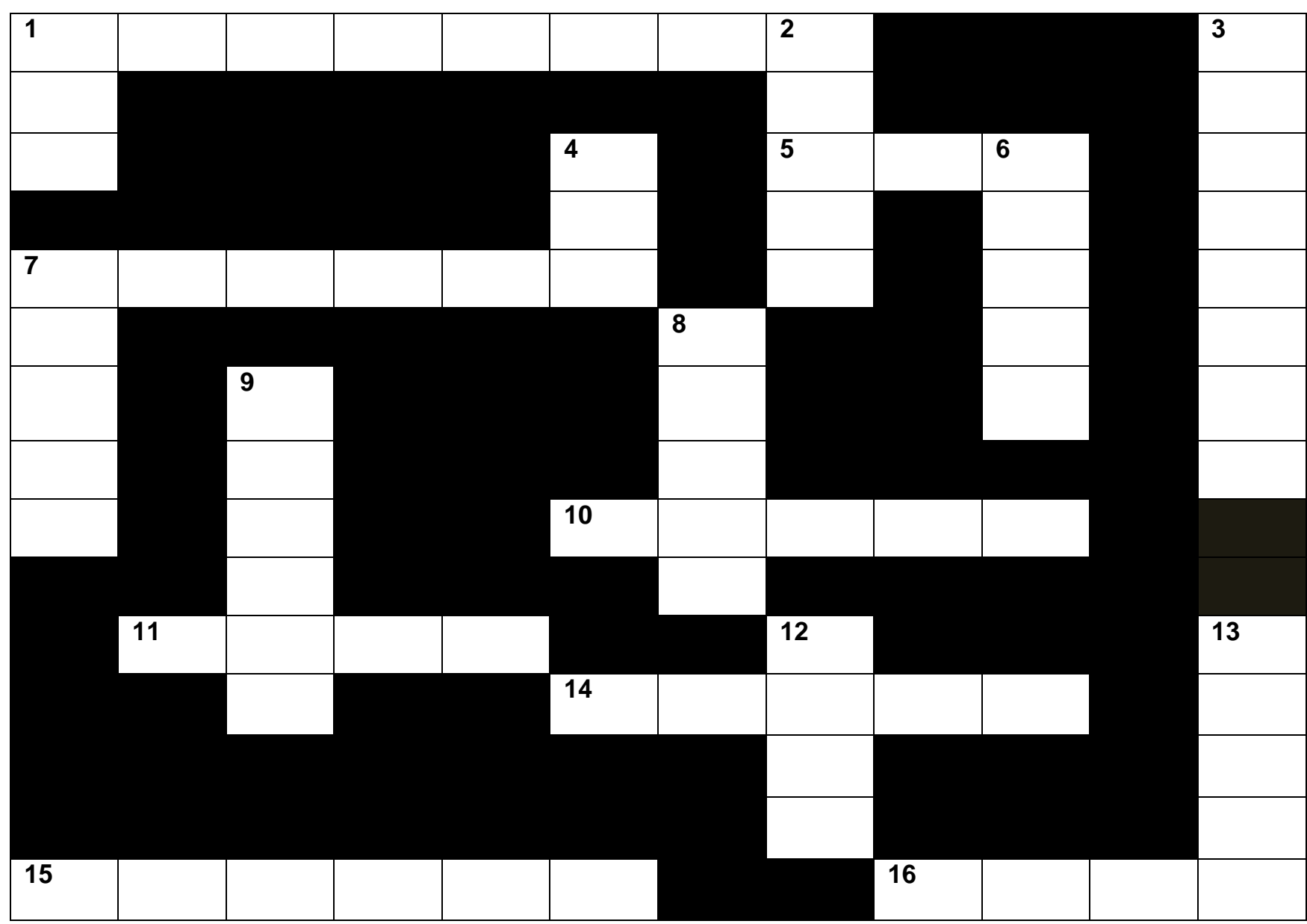

\begin{tabular}{|l|l|}
\hline Across & Down \\
\hline 1. trauzəz & 1. tai \\
5. kæp & 2. spks \\
7. dzækIt & 3. slipəz \\
10. dres & 4. hæt \\
11. belt & 6. pæns \\
14. bu:ts & 7. dzi:nz \\
15. blauz & 8. sk3:t \\
16. su:t & 9. glıvz \\
& 12. kəut \\
& 13. J3:t \\
& \\
\hline
\end{tabular}




\section{APPENDIX D:}

\section{The Telephone Number Activity}

Write down the number next to the word you hear, for a telephone number. Then, check your answer with a partner.

$\begin{array}{ll}0 \text { seat } & 1 \text { sit } \\ 2 \text { chart } & 3 \text { chat } \\ 4 \text { fool } & 5 \text { full } \\ 6 \text { short } & 7 \text { shot } \\ 8 \text { bird } & 9 \text { bud }\end{array}$

Now it's your turn. Conduct the activity with a partner. Good luck.

\section{APPENDIX E:}

\section{BINGO}

Cross out the words you hear. The first person to shout "BINGO" having made a line vertically

$(\searrow$ ), diagonally $(\downarrow$ ) or horizontally $(\longrightarrow$ ) wins.

\section{CARD 1}

\begin{tabular}{|l|l|l|l|}
\hline bird & fool & not & still \\
\hline feed & bud & full & heart \\
\hline chart & fed & shirt & shot \\
\hline short & pull & steal & chat \\
\hline shut & naught & hat & pool \\
\hline
\end{tabular}

CARD 2

\begin{tabular}{|l|l|l|l|}
\hline still & feed & pull & bud \\
\hline fool & pool & short & shirt \\
\hline chart & shot & not & fed \\
\hline full & heart & chat & bird \\
\hline hat & steal & shut & naught \\
\hline
\end{tabular}

CARD 3

\begin{tabular}{|l|l|l|l|}
\hline bird & pull & shut & chat \\
\hline fed & short & fool & still \\
\hline pool & feed & full & shot \\
\hline bud & hat & heart & chart \\
\hline naught & shirt & steal & not \\
\hline
\end{tabular}

CARD 4

\begin{tabular}{|l|l|l|l|}
\hline shut & short & hat & steal \\
\hline feed & bud & naught & pull \\
\hline fed & chart & fool & shirt \\
\hline full & bird & chat & shot \\
\hline pool & not & still & heart \\
\hline
\end{tabular}




\section{APPENDIX F:}

Listen to one of the sets and choose the word you hear.

\begin{tabular}{|c|c|}
\hline Set 1 & Set 2 \\
\hline Where has Don / Dawn gone? & He was short / shot. \\
\hline What does hurt / hut mean? & What does shut / shirt mean? \\
\hline It's fullish / foolish. & How do you spell pull / pool? \\
\hline The beans / bins are smelly. & I can't feel / fill it. \\
\hline Haven't you got a hat / heart? & Where's the pack / park? \\
\hline Set 3 & \\
\hline Look at the girls / gulls. & \\
\hline What does cord / cod mean? & \\
\hline There isn't any backing / barking. & \\
\hline Look at that sheep / ship. & \\
\hline How do you spell soot / suit? & \\
\hline
\end{tabular}

\section{Bio Data}

The author has been teaching for over 20 years. He has taught in Turkey, England, Thailand, Vietnam, where he became interested in the teaching of pronunciation, Singapore, and Saudi Arabia, before moving to Oxford where he currently works at Hertford College, Oxford University. As well as pronunciation, he is interested in learner styles. 